\title{
Who translates the Watchmen? (Re)traduire les héros marginaux d'Alan Moore
}

\section{French Abstract}

La retraduction est un phénomène essentiel au processus traductif. Elle est considérée comme la suite logique du processus permettant à l'œuvre littéraire traduite de se renouveler dans un espace culturel et langagier sans cesse en mouvement. Nous pouvons observer, dans une moindre mesure, que le même phénomène existe dans la traduction de la bande-dessinée. Cependant celleci demande d'autres compétences et une approche traductive quelque peu différente de la traduction d'œuvres littéraires, notamment par la présence du code sémiotique de l'image, lui aussi fortement lié à la culture dans lequel il est inscrit et aux changements que cette dernière subit continuellement.

La bande-dessinée Watchmen (ou Les Gardiens), d'Alan Moore et Dave Gibbons, est connue dans le monde entier comme le comic ayant non seulement révolutionné la vision des super-héros, mais ayant également donné une toute autre voix aux comic books. Watchmen est publié de 1986 à 1987 aux États-Unis et traduit à partir de 1987 par Jean-Patrick Manchette. Quinze ans seulement après cette première édition française, les éditions Panini décident en 2007 de retraduire ce célèbre comic. Cependant, si les critiques de la première sont élogieuses, la retraduction n'a pas été bien reçue par le public francophone. Cet article propose une analyse comparative de ces deux traductions et de leur version originale, ainsi qu'une expérimentation sur un lectorat amateur et non amateur de comics, afin d'établir les raisons du succès de la première et de l'échec de la deuxième. Ainsi, il sera possible de dégager les éléments permettant de comprendre la réception d'une traduction de bande-dessinée.

\section{English Abstract}

The retranslation phenomenon is essential to the translation process. It is considered as the logical progression of this process which allows the translated literary work to regenerate in a restless cultural and language space. To a lesser extent, we can observe the same phenomenon in the translation of comics. However, this specific translation requires other competencies and a translating approach somehow different from the ones required to translate fiction literature, especially because of the presence of the visual system of drawings which is strongly bound to its own culture and the endless mutations it goes through.

The comic book Watchmen (Les Gardiens, in the first French translation) by Alan Moore and Dave Gibbons, is known in the whole world as the comic which had not only remodeled the vision we had of super-heroes, but had also given the comic books another voice. Watchmen was published between 1986 and 1987 in the United States and translated in French from 1987 to 1988. Fifteen years after this first translation by Jean-Patrick Manchette, Panini publishing decided to retranslate this famous comic in 2007. However, if the reviews of the first translation were laudatory, the retranslation did not enjoy a great reception from the readers or from the reviewers. This paper proposes a comparative analysis of both these translations and of their original version as well as an experiment on the readers, comic books readers or not, in order to 
establish why the first translation was a success and the retranslation a failure. Thus, we could withdraw the elements which allow us to understand the reception of comic translation. 